\title{
Pneumologia
}

\section{Beating the virus is not enough}

Florin Mihățan ${ }^{1, *}$, Ancuța Constantin ${ }^{2}$

${ }^{1}$ National Institute of Pneumology "M.Nasta", Bucharest, Romania
2Carol Davila university of medicine and pharmacy, Bucharest, Romania

Abstract

\section{English:}

The authors are presenting a case reflecting the evolution of an infected patient representing the source and, at the same time, one of the first severe cases of SARS-COV2 in Romania, burdened by a dragging and difficult evolution both by the nature of a newly identified infection, with real treatment deficiencies, and by deliberate omission of ethical aspects. There was a delay and were considerable difficulties in establishing the diagnosis, the evolution of the disease, along with some other consequences like an increase in the risk of transmitting the infection - a vicious cycle that otherwise could have been interrupted much earlier.

Keywords

\section{Să învingi virusul nu este suficient}

\section{Rezumat}

\section{Romanian:}

Autorii prezintă un caz care reflectă evoluția unui pacient infectat reprezentând sursa și, în același timp, unul dintre primele cazuri severe de SARS-COV2 în România, împovărat de o evolutie dificilă și prelungită atât prin natura unei infectiii nou identificate, cu deficiențe reale de tratament, dar și prin aspecte etice omise în mod deliberat; a fost o întârziere și dificultăți considerabile în stabilirea diagnosticului, în evoluția bolii, cu alte consecințe precum creșterea riscului de transmitere a infecției, un cerc vicios care altfel ar fi putut fi întrerupt mult mai devreme.

Cuvinte-cheie

COVID19 • pneumonie severă • sechelă

\section{Introduction}

Covid-19 infection remains unprecedented and unforgettable in the memory of all Romanians who were urged to stay indoors for many weeks during the Easter Period after the outbreak of this novel viral disease. The epidemic started in Wuhan, China, and quickly spread throughout the entire country and to nearly 50 other countries all over the world (1). There are many survivors at this moment, even after severe pneumonia, but few articles are describing its consequences in long term.

\section{Clinical case}

We present the case of a male, 61-year-old, known to have cardiovascular risk factors (smoker, hypertensive, diabetic, obese, age, sex), who has a chronic infection with hepatitis B virus (HBV) (under treatment with entecavir), diabetes mellitus, obstructive sleep apnoea (OSA - total therapeutically neglected) and continuous positive airway pressure (CPAP) indication since 2016. The patient states non-specific polymorphic symptomatic onset with chest myalgias, abdominal pain, diarrhoea, about approximately a

*Corresponding author: Florin Mihățan

E-mail:mihaltan@starnets.ro 
month and a half prior to presentation in our clinic; symptoms progressively accentuated over the last 10 days. With this persistent symptomatic sufferance, he presents at the emergency department (ED) of a multidisciplinary hospital; shortly after admission, he was adding new elements in the clinical picture, with dry cough and frontal headache, these new conditions requiring finally hospitalization. The radiological examination performed at this time did not identify significant pathological changes (Figure 1) and, although initially there was a slight symptomatic improvement during the first days, later he develops febrile syndrome, dyspnoea with orthopnoea, symptomatic exacerbation unpredicted by previous evolution. In February 2020 - the current global epidemiological epicentre was still relatively far from Romania, but considering the unfavourable clinical evolution with accentuation of symptoms and the fragile epidemiological status worldwide, it was recommended the SARS-COV2 PCR test. He was anamnestic and it was noted that there were certain denial and absence of any particular signs of travel to endemic SARS-COV2 areas or contact with people with respiratory conditions. However, after receiving positive result for SARS-COV2 infection, the patient reverted the previously mentioned information informing the medical staff about an epidemiological context to which he was exposed, being recently returned from a risk area, soon after becoming symptomatic. Meanwhile, it was a progressive clinical degradation with rapid impairment of respiratory and blood gas analysis functional parameters, subsequently requiring transferring of this patient to Infectious Diseases Department (IDD), with a poor general condition, dyspnoea, persistent thoracic myalgia, conscious but unable to clearly cooperate. CT scan (Figure 2) raised the problem of a bronchopneumonic disease expression of the COVID 19 infection.
First biological balance sheet showed leucocytosis with neutrophilia, lymphopenia, biological inflammatory syndrome, hypokalaemia, hypoalbuminemia, hepatic cytolysis syndrome, mild hypocalcaemia, muscle cytolysis syndrome, hyperglycaemia, nitrogen retention, increased D-dimers (388 ng CO mL) positive and Ag HBs positive.

Corroborating clinical, biological and imagistic data (X-ray - Figure 3), the case was considered as acute hypoxemic respiratory failure and bronchopneumonia with

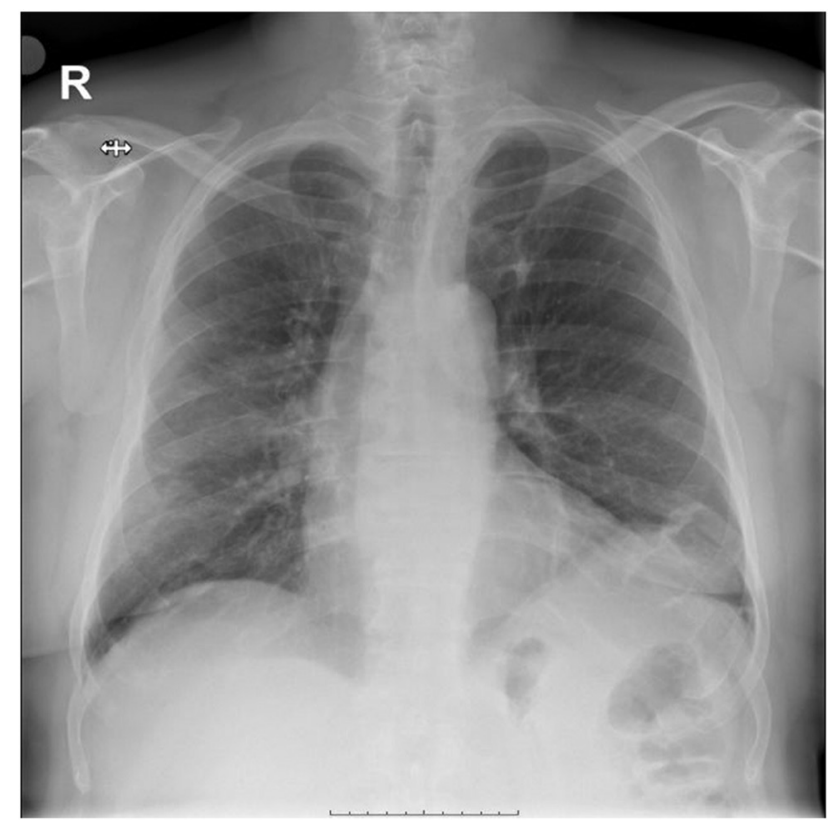

Figure 1. X-ray ED (05 March 2020). Without any inflammatory signs. ED, emergency department.
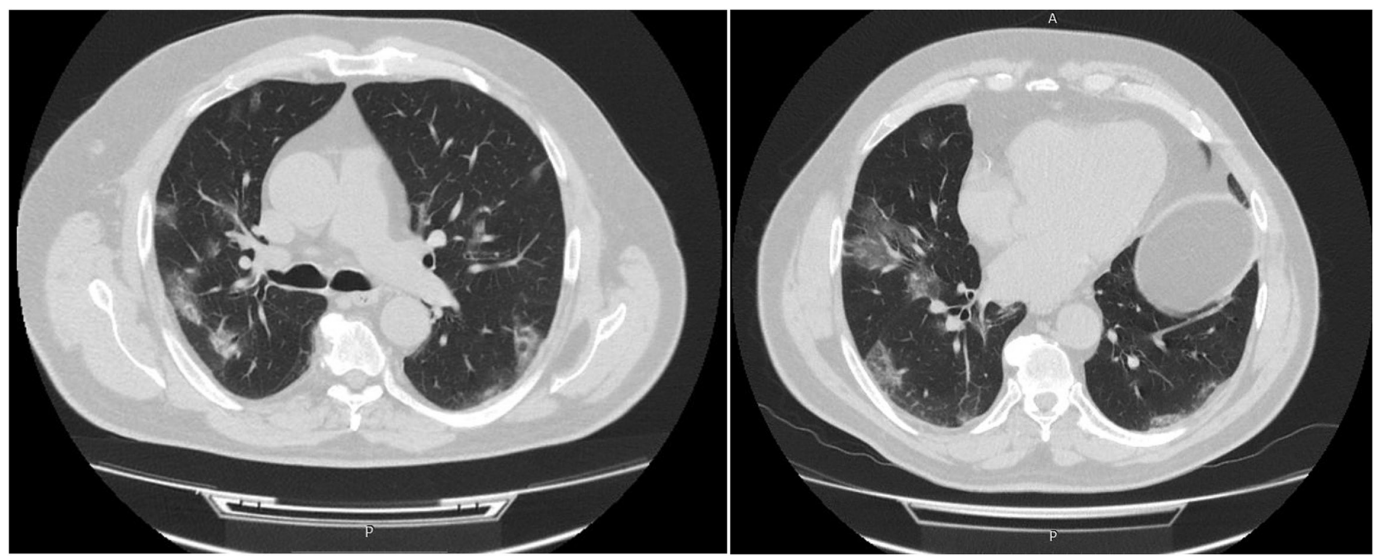

Figure 2. CT scan of thorax (06 March 2020): Areas of mixed interstitial and alveolar pulmonary infiltrates, diffusely distributed in both lung fields; small mediastinal lymphadenopathy; left diaphragmatic relaxation with discrete adjacent ventilation disorders. 
acute respiratory distress syndrome (ARDS) due to SARSCOV2 infection, initiating antiviral therapy (Kaletra, oseltamivir), antibiotics (ceftriaxone, levofloxacin), hydroxychloroquine, fibrinolysis with Actylise, followed by anticoagulant therapy, corticotherapy, insulin therapy, hydro-electrolytic, acid-base rehydration solutions, oxygenotherapy and personal therapy for cardiological use. Clinical evolution became slightly favourable.

Further imaging evolution (CT scan 17 March 2020) (Figure 4) was confirmed a progression of the disease.

Later on, clinical and biological evolution was slowly progressed towards improvement, with the patient maintaining optimal saturations below oxygen therapy $2.5 \mathrm{~L} / \mathrm{min}$. Imagistically, however, it remained quite stationary (Figure 5 ).

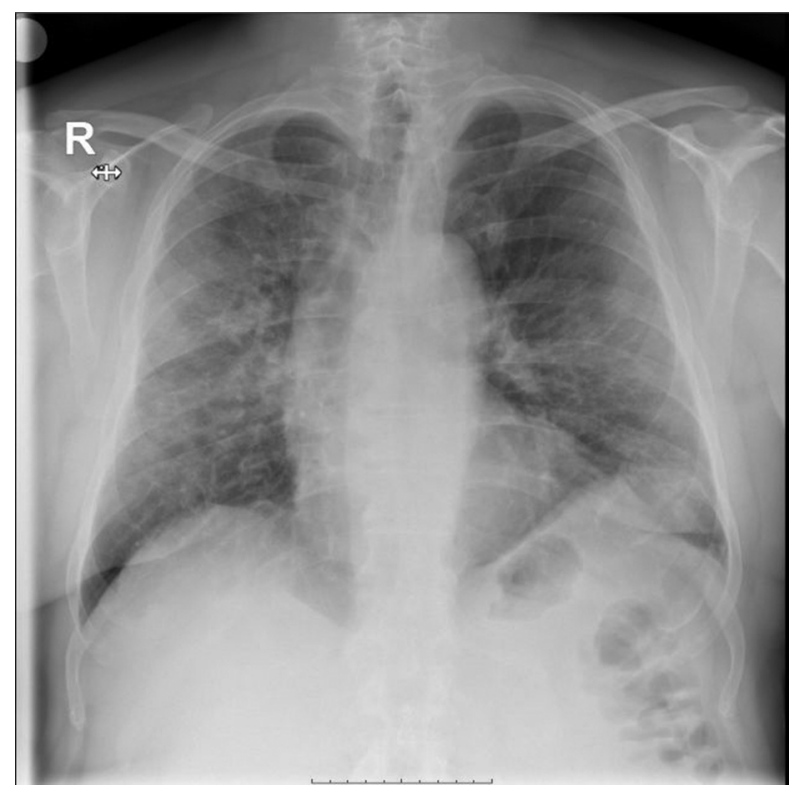

Figure 3. X-ray on admission - ICU (09 March 2020). Alveolointerstitial condensations of bronchopneumonic type affecting both lung fields, with centripetal appearance.
After 3 weeks of admission in ICU, noticing a clinically and biologically favourable evolutionary aspect, with two SARSCOV2 negative control tests, it was decided to transfer the patient to the hospital ward. He was keeping still moderate symptoms with dyspnoea at minimal effort, partially controlled under oxygen. He was discharged on the 27th day of hospitalisation with mandatory recommendations of maintaining isolation at home for another 14 days from the date of discharge, with strict rules of social distance. Oxygen therapy at home was indicated due to dyspnoea at low effort. On April 2020, 3 weeks later, the patient came to Marius Nasta Institute for respiratory reassessment, reporting persistent dyspnoea at moderate exertion but with an increase in exercise tolerance, without any other accompanying symptoms, haemodynamically and respiratory balanced ( $\mathrm{TA}=135 / 80 \mathrm{~mm} \mathrm{Hg}, \mathrm{AV}=76 \mathrm{bpm}, \mathrm{SaO}_{2}=92-93 \%$ aa).

Anew balance sheet with a native CT scan (Figure 6) highlights certain favourable evolution of lung parenchymal lesions.

On plethysmography + TLCO we found that (Figure 7) the patient had a moderate restrictive ventilatory dysfunction with vital capacity (VC) reduction by $31.8 \%$. There was no response to Ventolin. The gas transfer factor through the alveolar capillary membrane was moderately low (DLCO $\mathrm{C}=53.3 \%, \mathrm{KCOC}=85.4 \%$ ).

Blood gases: $\mathrm{Ph}=7,43, \mathrm{P}$ O2 $=85,7 \mathrm{mmHg}$, $\mathrm{P} \mathrm{CO} 2=36,7 \mathrm{mmHg}, \mathrm{SaO}_{2}=96,7 \%$ aa. 6 minute walk test (6 MWT) would have been useful in the indirect evaluation of the effort capacity, but the absence of an epidemiological circuit in this sense excludes its performance.

Corroborating clinical and paraclinical data, our diagnosis was interstitial lung fibrosis sequelae as a late complication of COVID 19 disease. We considered appropriate the onset of low-dose cortisone therapy - Predison $10 \mathrm{mg} / \mathrm{day}$, for 30 days, with subsequent monthly monitoring of blood sugar, tuberculosis sputum bacteriological examination and mycological investigation, given the presence of cavity image localised RIL. We also recommend to start CPAP therapy.
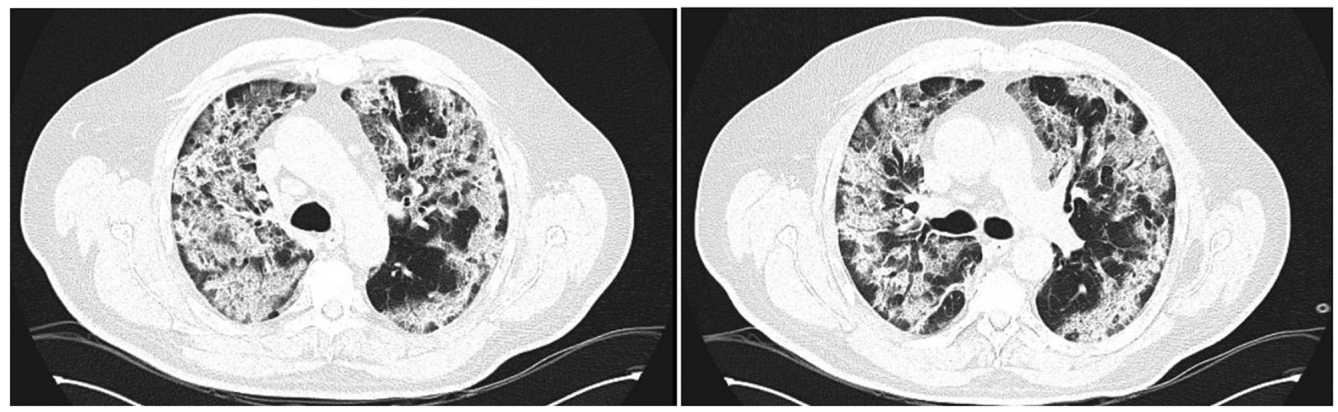

Figure 4. CT scan on 17 March 2020: bilateral alveolar-interstitial densifications with the main interstitial component, partially confluent, affecting both lungs, presenting a predominantly peripheral distribution at left inferior lobe (LIL), right inferior lobe (RIL), medium lobe (ML) and unsystematised at right upper lobe (RUL), left upper lobe (LUL). There was a minor pulmonary embolism on the posterior segmental branch of the right inferior lobe pulmonary artery. 

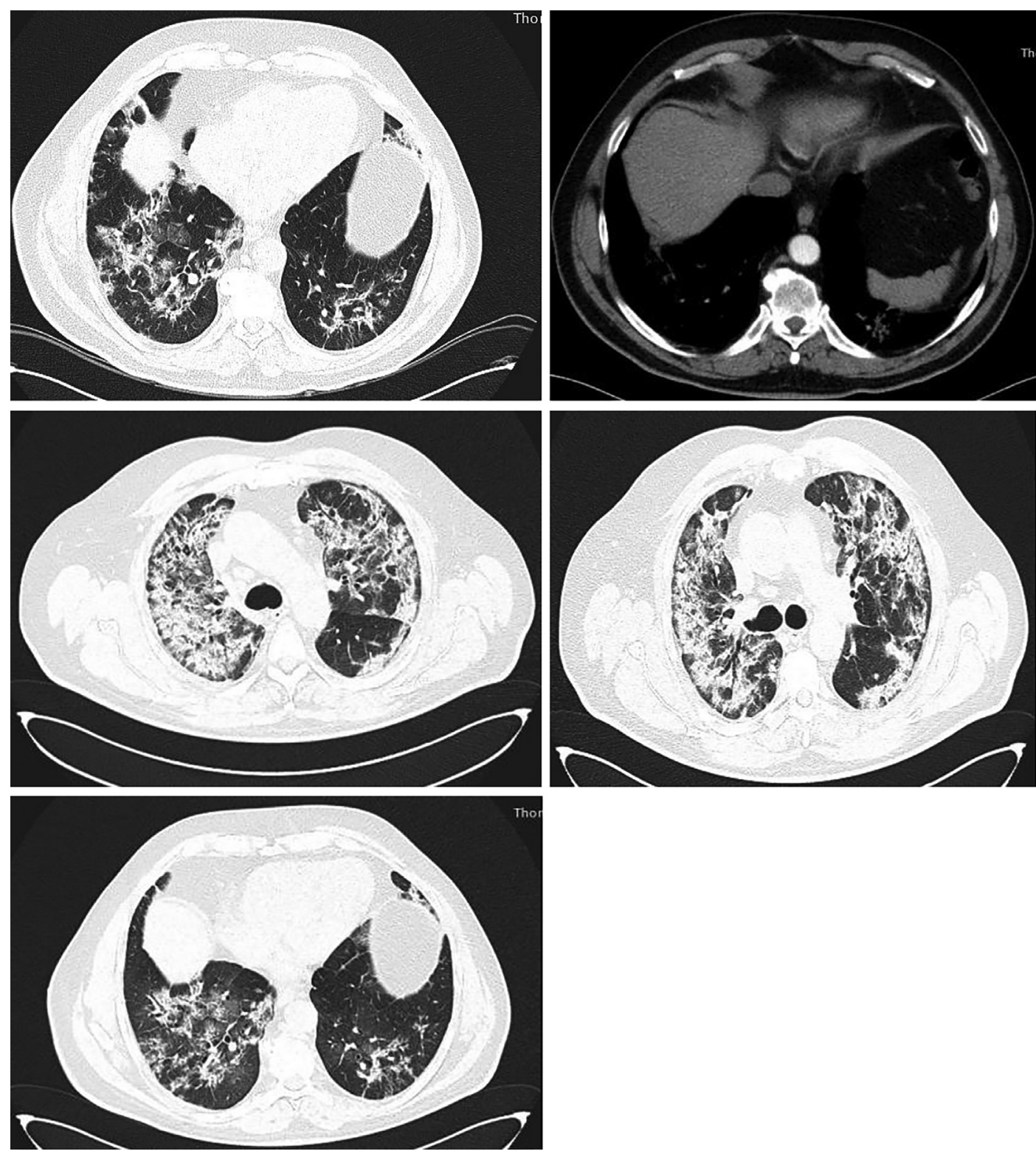

Figure 5. CT scan on 01 April 2020: slight reduction in the projection area of bilateral interstitial densification foci; the mediastinal lymphadenopathy is kept numerically and dimensionally stationary. Without pleural collections, homogeneous opacified pulmonary arteries.

A week later, a discreet improvement of effort dyspnoea is noted anamnestically, the next period remaining is still decisive for the course of the disease evolution.

\section{Discussion}

There are few reports concerning the late complications of coronavirus infections. Looking at the survivors from another coronavirus epidemic event, the Middle East Respiratory
Syndrome (MERS) (2) from 2015, we found reports of severe pneumonia correlated with long-term sequelae. More severe MERS pneumonia can result in more impaired lung function for at least 1 year after MERS-CoV infection. In all, $24 \%$ of SARS survivors have impaired DLCO and $5 \%$ reduced lung volume at 12 months (3). Our case had an early lung function dysfunction after almost 2 months from the start of infection. A mild reduction of DLCO may persist in up to $80 \%$ of the patients in 1 year after recovery (4). We also hope to obtain a return to normal function, as already described by other 

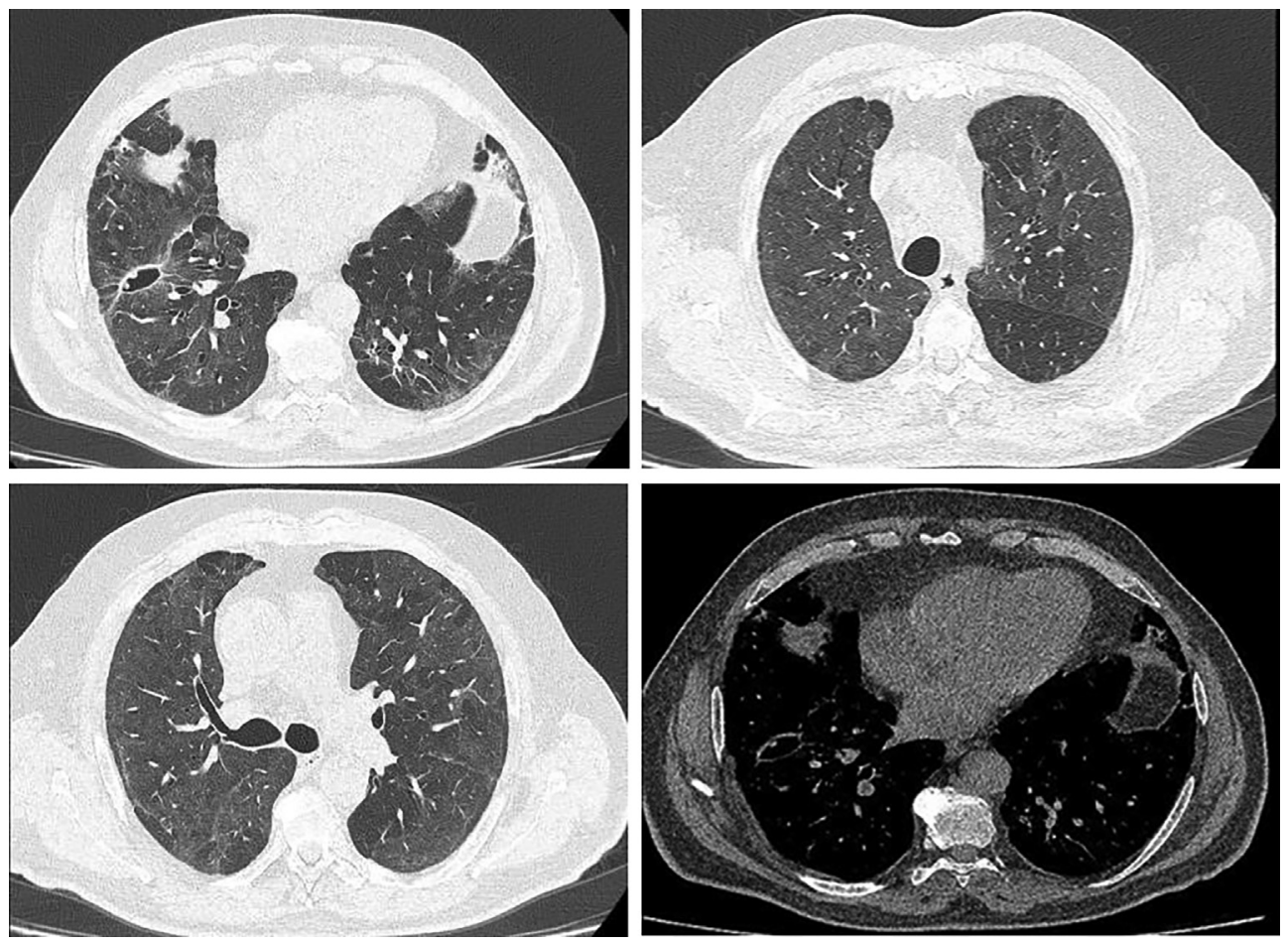

Figure 6. CT scan: small cavity lesion developed in the anterior segment of the RIL in contact with the oblique fissure. Interstitial densifications with fibrotic appearance.

experts, in 6-12 months after ARDS (5). Some patients who recovered from Covid-19 have suffered reduced lung function and now experience problems such as gasping for air when walking quickly, Hong Kong's Hospital Authority has revealed (6). The worst chest radiographic findings often parallel the most severe extent of the disease (7). Prognostic factors for COVID are (1) age, gender, pregnancy, viral load, and underlying diseases. Probably in our case, diabetes, obesity, cardiovascular disease and OSA, together with the viral load where multiple factors facilitating the evolution of the disease. Chest CT signs improvement began after 14 days from the onset of the symptoms in $75 \%$ of cases with gradual resolution of the consolidation (8). Consolidation and ground glasses are very frequent, linear findings are less present and there are no cavity lesions described by radiologists. In our case, the resolution was starting very late but linear and cavity were presented after 2 months. Corticosteroids should not be routinely used in patients with COVID-19 for treatment of viral pneumonia or ARDS, unless indicated for other conditions such as asthma or chronic obstructive pulmonary disease (COPD) exacerbation, or septic shock (9). Even so, careful use of corticosteroids in low-to-moderate doses in short courses is advised. Hyperglycaemia, hypernatremia and hypokalaemia are the most common adverse effects associated with corticosteroid use and should be routinely monitored $(10,11)$.
For our patient, we choose low doses of corticosteroids and he will be strictly monitored having also the diabetes mellitus as a comorbidity. The anti-inflammatory medication such as corticosteroid was found to be the most mentioned and widely used medicine in these COVID-19 studies, despite the safety alert issued by $\mathrm{WHO}$ and $\mathrm{CDC}$, followed by antiviral medication lopinavir, oseltamivir and Arbidol hydrochloride (12). Despite the long history of administering corticosteroids, their therapeutic effectiveness and safety remain controversial. Several clinical trials and meta-analyses have indicated that corticosteroids are associated with increased mortality, a tendency for requiring mechanical ventilation therapy, and relatively longer hospitalisations for SARS, MERS and H1N1 infections (13). According to the Guidelines for the Diagnosis and Treatment of COVID19 (7th edition) in China (NHPFC, 2020), however, prudent low-to-moderate doses of corticosteroids could yield potential therapeutic benefits for a subset of seriously ill patients with COVID-19 pneumonia - recommendations in line with the interim clinical management guidance for COVID-19 released by the World Health Organization, which advised against routinely administering corticosteroids except for clinical indications such as exacerbated COPD and septic shock (WHO, 2020) (14). This was also our argument for recommending a low dose of corticosteroids after the acute moment of the disease. For survivors of the SARS epidemic, 


\section{Pletismografie si curbe flux-volum}

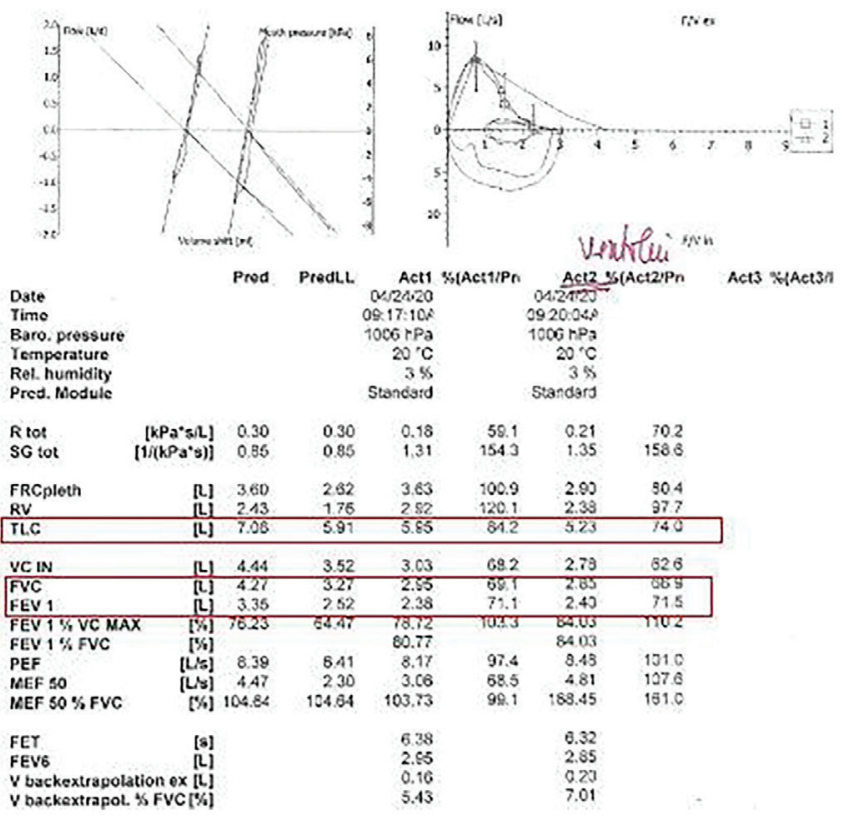

Difuziune alveolo-capilara

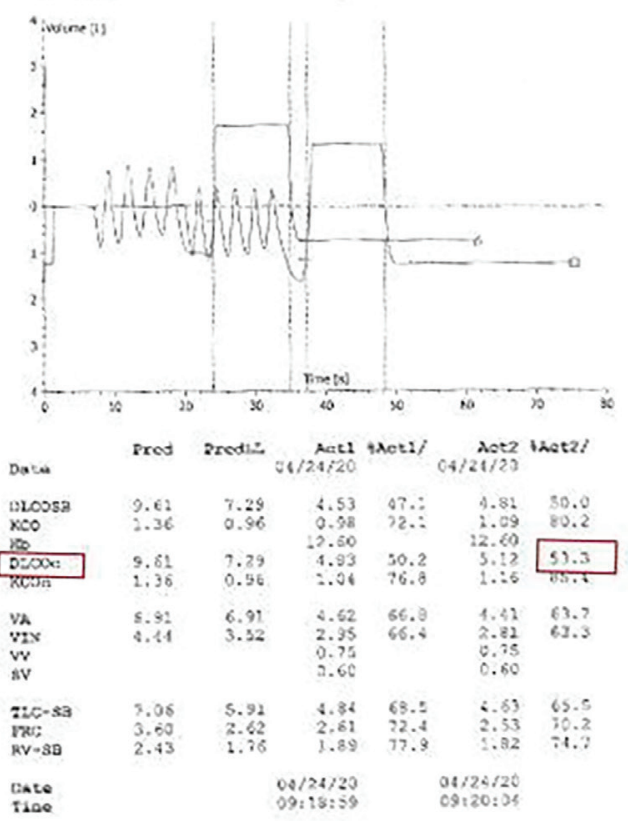

Figure 7. Plethysmography + TLCO.

a high rate of pulmonary fibrosis is reported (15). There are a few newly emerged fibrosis cases in COVID-19 patients (16) and COVID-19 survivors (like our patient) and they should be followed-up closely.

\section{Conclusion}

Our case report is demonstrating that for survivors it is not enough beating the viral infection, the damage you can have is for a lifetime and complications can last a 'lifetime'.

\section{Ethical approval}

Informed consent was obtained.

\section{Conflict of interest}

No conflict of interest.

\section{References}

1. Yi Y, Lagniton PNP, Ye S, Li E, Xu RH. COVID-19: what has been learned and to be learned about the novel coronavirus disease. International Journal of Biological Sciences. 2020;16(10): 1753-1766. Available from: http://www.ijbs.com/ v16p1753.htm.

2. Park WB, Jun KI, Kim G, Choi JP, Rhee JY, Cheon S, et al. Correlation between pneumonia severity and pulmonary complications in middle east respiratory syndrome. Journal of Korean Medical Science. 2018;33(24): e169. Available from: doi:10.3346/jkms.2018.33.e169.

3. Hui DS, Wong KT, Ko FW, Tam LS, Chan DP, Woo J, et al. The 1-year impact of severe acute respiratory syndrome on pulmonary function, exercise capacity, and quality of life in a cohort of survivors. Chest. 2005;128(4): 2247-2261.

4. Orme J Jr, Romney JS, Hopkins RO, Pope D, Chan KJ, Thomsen G, et al. Pulmonary function and health-related quality of life in survivors of acute respiratory distress syndrome. American Journal of Respiratory and Critical Care Medicine. 2003;167(5): 690-694.

5. Peters JI, Bell RC, Prihoda TJ, Harris G, Andrews C, Johanson WG. Clinical determinants of abnormalities in pulmonary functions in survivors of the adult respiratory distress syndrome. The American Review of Respiratory Disease. 1989;139(5): 1163-1168.

6. Cheung E. Coronavirus: some recovered patients may have reduced lung function and are left gasping for air while walking briskly, Hong Kong doctors find. South China Morning Post Published: 12:04 am, 13 Mar, 2020.

7. Wang JT, Sheng WH, Fang CT, Chen YC, Wang JL, Yu CJ, et al. Clinical manifestations, laboratory findings, and treatment 
outcomes of SARS patients. Emerging Infectious Diseases. 2004;10: 818-824.

8. Kanne JP. Chest CT findings in 2019 novel coronavirus (2019-nCoV) infections from Wuhan, China: key points for the radiologist. Radiology. 2020;295: 16-17.

9. Russell CD, Millar JE, Baillie JK. Clinical evidence does not support corticosteroid treatment for 2019-CoV lung injury. Lancet. 2020;395: 473-475.

10. Lamontagne F, Rochwerg B, Lytvyn L. Corticosteroid therapy for sepsis: a clinical practice guideline. BMJ. 2018;362: 1-8.

11. Chen C, Qi F, Shi K, Li Y, Li J, Chen Y, et al. Thalidomide combined with low-dose glucocorticoid in the treatment of COVID-19 pneumonia. Preprints. 2020:2020020395. Available from: https://www.preprints.org/manuscript/202002. 0395/v1.

12. Tobaiqy M, Qashqary M, Al-Dahery S, et al. Therapeutic management of COVID-19 patients: a systematic review [pub- lished online ahead of print, 2020 Apr 17]. 2020;2(3): 100061 doi:10.1016/j.infpip.2020.100061.

13. Arabi YM, Mandourah Y, Al-Hameed F, Sindi AA, Almekhlafi GA, Hussein MA, et al. Corticosteroid therapy for critically ill patients with middle east respiratory syndrome. American Journal of Respiratory and Critical Care Medicine. 2018;197: 757-767.

14. Kakodkar P, Kaka N, Baig MN. A comprehensive literature review on the clinical presentation, and management of the pandemic coronavirus disease 2019 (COVID-19). Cureus. 2020;12(4): e7560. doi:10.7759/cureus.7560.

15. Venkataraman $T$, Frieman $M B$. The role of epidermal growth factor receptor (EGFR) signaling in SARS coronavirus-induced pulmonary fibrosis. Antiviral Research. 2017;143: 142-150.

16. Zhang W. Imaging changes of severe COVID-19 pneumonia in advanced stage. Intensive Care Medicine. 2020;46: 841-843. [Google Scholar]. 